\title{
Membaca Fenomena Kabar Bohong Pilpres 2019 di Indonesia Berdasarkan Kaca Mata Herbert Marcuse, Jürgen Habermas, dan Zygmunt Bauman
}

\author{
Reading the Phenomenon of Hoax during the 2019 Presidential General Election Membaca \\ under the Eyeglasses of Herbert Marcuse, Jürgen Habermas, and Zygmunt Bauman
}

\author{
Yohanes Wahyu Prasetyo \\ Staff JPIC OFM Indonesia dan Mahasiswa Magister Filsafat STF Driyarkara \\ E-mail: yohanes.wahyup@driyarkara.ac.id
}

\begin{abstract}
Hoaxes were rampant before, during and after the 2019 presidential election. According to Herbert Marcuse's point of view, the hoax phenomenon is closely related to capitalism, hence prioritizing profit gaining and ignoring truth. Consequently, the people are seen as things and objects. Further, according to Jürgen Habermas, the hoax phenomenon takes place because of lack of communicative dialog and ethical responsibility where mass media are used as weaponry means by political parties to make public opinions. In the meantime, Zygmunt Bauman is of the opinion that the hoax phenomenon demonstrates that the people are treated as outsiders, foreigners and the out-group.
\end{abstract}

Keywords: Marcuse, Habermas, Bauman, capitalism, communicative dialog, outsiders, hoax, and 2019 presidential election

\begin{abstract}
Abstraksi
Kabar bohong atau hoaks merajalela sebelum, pada saat, dan sesudah Pilpres 2019. Berdasarkan kaca mata Herbert Marcuse, fenomena kabar bohong terkait erat dengan sistem kapitalisme, mementingkan keuntungan dan mengabaikan kebenaran. Sehingga masyarakat dilihat sekadar sebagai benda dan objek. Selanjutnya, berdasarkan kaca mata Jürgen Habermas, fenomena kabar bohong terjadi karena lemahnya dialog komunikatif dan tanggung jawab etis, di mana media digunakan sebagai senjata opini partai politik. Sedangkan berdasarkan kaca mata Zygmunt Bauman, fenomena kabar bohong memerlihatkan bahwa masyarakat diperlakukan sebagai orang luar, orang asing, dan orang lain.
\end{abstract}

Kata Kunci: $\quad$ Marcuse, Habermas, Bauman, kapitalisme, dialog komunikatif, orang luar, kabar bohong, dan Pilpres 2019

\section{Pendahuluan}

Herbert Marcuse (1898-1979) menggambarkan masyarakat modern sebagai satu dimensi (one-dimensional). Situasi dan kondisi tersebut seringkali membuat masyarakat mengalami penindasan, penderitaan, represi, dan trauma. Selanjutnya, Jürgen Habermas (1929- ) melihat masyarakat modern terkoyak oleh konflik antara dunia kehidupan (lifeworld) dan sistem reproduksi (systems reproduction). Selain itu, kehidupan masyarakat didominasi budaya kapitalis, birokrasi, dan teknologi. Sedangkan menurut Zygmunt Bauman (1925-2017), modernitas ringan yang didasarkan pada deregulasi ekonomi mewarnai kehidupan masyarakat.

Supaya dapat memahami gagasan Herbert Marcuse, Jürgen Habermas, dan Zygmunt Bauman tersebut dalam kaitannya dengan fenomena kabar bohong Pilpres 2019 di Indonesia dengan baik, penulis menguraikan tulisan ini ke dalam empat bagian. Pertama, Herbert Marcuse: masyarakat modern mengalami penindasan, penderitaan, represi, dan trauma. Kedua, Jürgen Habermas: masyarakat modern 
didominasi budaya kapitalis, birokrasi, dan teknologi. Ketiga, Zygmunt Bauman: masyarakat modern diwarnai deregulasi ekonomi. Keempat, membaca fenomena kabar bohong pilpres 2019 di Indonesia berdasarkan kaca mata Herbert Marcuse, Jürgen Habermas, dan Zygmunt Bauman.

\section{Herbert Marcuse: Masyarakat Modern Mengalami Penindasan, Penderitaan, Represi, dan Trauma}

Menurut Marcuse, logika kapitalisme dipaksakan melalui budaya periklanan, pemasaran, dan hiburan (Lemert dan Elliott, 2014: 57). Kapitalisme beroperasi pada tataran yang tidak disadari (unconscious level). Hal ini disebut sebagai desublimasi represif (repressive desublimation). Berdasarkan sistem kapitalisme, masyarakat terlibat dalam lanskap komoditas dan upah serta harga dan keuntungan. Akibatnya, masyarakat merasa puas ketika selera (appetites) dan keinginan (desires) diatur serta dikendalikan.

Sebagaimana ditegaskan Marcuse, budaya modern pada dasarnya bersifat represif (Lemert dan Elliott, 2014: 58). Dalam upaya mengatasi persoalan tersebut, Marcuse membuka perspektif baru dalam teori sosial kritis dengan mengacu pada psikoanalisis Sigmund Freud (1856-1939). Terkait hal ini, Marcuse melihat kapitalisme merambah ke dalam pengalaman hidup dan subjektivitas pribadi manusia. Kapitalisme mengejawantah dalam rupa mekanisasi dan standarisasi teknologi yang tertanam di dalam identitas manusia.

Pada 1950 masyarakat Amerika masuk kategori paling kaya dan maju dalam bidang industri. Namun, kemakmuran ekonomi tersebut bertolak belakang dengan kehidupan masyarakat yang dibatasi (constrained), terutama terkait aspek emosional dan relasi interpersonal (interpersonal relationship). Menurut Marcuse, represi yang dialami masyarakat kontemporer dalam bentuk penindasan terus meningkat (Lemert dan Elliott, 2014: 59). Selain itu, kehidupan masyarakat diwarnai dengan harga (prices) dan keuntungan (profits) serta uang (money) dan korporasi monopoli (monopolistic corporations).

Marcuse membedakan dua macam represi, yaitu represi dasar (basic repression) dan represi surplus (surplus repression) (Lemert dan Elliott, 2014: 59). Represi dasar mengacu pada penolakan menghadapi kehidupan sosial dan tugastugas budaya. Menurut Marcuse, penindasan diperlukan dalam rangka mengaktualisasikan sosialisasi dan tatanan sosial yang efektif. Sedangkan represi surplus mengacu pada intensifikasi pengekangan diri (self-restraint) yang disebabkan oleh eksploitasi kapitalis dan relasi kekuasaan yang asimetris.

Marcuse meyakini bahwa represi merupakan hasil dari prinsip kinerja (performance principle), di mana tuntutan sosial budaya tertentu dilembagakan oleh tatanan ekonomi kapitalisme (Lemert dan Elliott, 2014: 59). Prinsip kinerja kapitalis tersebut membuat manusia memandang yang lain sebagai benda (things) atau objek (objects). Pada abad XX, kehidupan pribadi dan sosial manusia ditarik menuju dua arah dalam waktu bersamaan. Terkait hal ini, muncul masyarakat industri maju. Selain itu, perjumpaan manusia dengan budaya menjadi lebih dekat, kompleks, dan halus.

Pada era konsumerisme massa dan budaya populer, tatanan sosial baru membatasi individualitas, perbedaan pendapat, dan oposisi (Lemert dan Elliott, 2014: 60). Selain itu, kapitalisme maju menghasilkan masyarakat satu dimensi (onedimentional society), di mana kebutuhan masyarakat sebagai konsumen bersifat palsu (false). Selanjutnya, manusia diintegrasikan ke dalam sistem dominasi massa dan 
ketidaksetaraan sosial. Dengan kata lain, ciri menonjol dunia modern adalah kesesuaian (conformity). Akibatnya, desublimasi yang merajalela dalam masyarakat industri maju mengungkap fungsi konformisnya (Marcuse, 1964: 76).

Sebagaimana dikatakan Marcuse, prinsip kinerja menghasilkan budaya yang diperlukan untuk transformasi masyarakat (Lemert dan Elliott, 2014: 61). Sedangkan represi surplus menghasilkan kemajuan teknologi industri. Selain itu, kemakmuran materi yang dihasilkan industrialisasi kapitalis Barat dan ilmu teknologi membuka jalan bagi terurainya represi. Terkait hal ini, tindakan mengatasi dominasi budaya berdampak pada lepasnya kekuatan bawah sadar manusia yang tertekan.

Rekonsiliasi antara budaya dan alam bawah sadar mengantar manusia pada realitas baru yang sensual. Sebuah realitas yang disebut Marcuse sebagai rasionalitas libidinal (libidinal rationality) (Lemert dan Elliott, 2014: 61). Rasionalitas libidinal pada hakikatnya bersifat abstrak. Tetapi sebagai sebuah konsep, rasionalitas libidinal memungkinkan pembalikan radikal dari surplus represi. Rasionalitas libidinal dapat diartikan sebagai pendorong komunikasi emosional (emotional communication) dan keintiman (intimacy) (Lemert dan Elliott, 2014: 61).

\section{Jürgen Habermas: Masyarakat Modern Didominasi Budaya Kapitalis, Birokrasi, dan Teknologi}

Habermas meyakini asumsi dasar pencerahan (enlightenment) yang terkait dengan kebebasan (freedom) dan solidaritas (solidarity) mampu mentransformasi masyarakat (Lemert dan Elliott, 2014: 257). Dalam kebebasan dan kesetaraan, setiap orang dituntut mengambil perspektif orang lain serta memproyeksikan dirinya ke dalam perspektif orang lain tersebut dan juga diri sendiri (Habermas, 1995: 117).

Habermas menjadikan bahasa sebagai landasan teori sosial, sarana memahami kekuatan rasionalitas dalam kehidupan sehari-hari. Karena bahasa selalu berorientasi pada kesepakatan dan konsensus bersama. Hal ini terlihat dalam kapasitas manusia yang paling mendasar, yaitu berbicara (speaking), mendengar (hearing), bernalar (reasoning), dan berargumentasi (argumentation).

Habermas sejatinya menekankan pendekatan radikal terhadap kebenaran melalui dialog komunikatif (communicative dialogue) (Lemert dan Elliott, 2014: 258). Sebagaimana ditegaskan Habermas, dialog komunikatif memungkinkan kebebasan (freedom), kesetaraan (equality), kebersamaan (mutuality), dan tanggung jawab etis (ethical responsibility).

Habermas membedakan antara ruang publik (public sphere) dan kehidupan pribadi (private live) (Lemert dan Elliott, 2014: 258). Terkait hal ini, ruang publik di Yunani kuno dibentuk sebagai arena dialogis, tempat di mana setiap orang datang untuk bertemu dan terlibat dalam diskursus publik. Dengan menurunnya peradaban Yunani kuno, keterlibatan di dalam ruang publik menghilang.

Menurut habermas, munculnya ruang publik borjuis dapat dilacak dalam berbagai forum diskusi publik. Selain itu, surat kabar dan jurnal mingguan digunakan para cendekiawan untuk berdebat serta mempertanyakan otoritas politik dan perilaku pemimpin negara. Namun, seringkali surat kabar menjadi senjata opini partai politik (weapons of party politics) (Lemert dan Elliott, 2014: 259).

Habermas memerlihatkan bahwa dalam demokrasi massa yang maju, aspek kritis ruang publik mengalami penurunan (Lemert dan Elliott, 2014: 260). Komersialisasi media mengubah ruang 
publik borjuis menjadi wadah kritik politik dan pengambilan keputusan publik. Komersialisasi media dan pertumbuhan industri berakibat pada menurunnya keterlibatan sipil serta kualitas debat politik publik.

Perlu diketahui bahwa modernitas menggabungkan rasionalitas yang mematikan (lethal) dan konsumerisme yang menggoda (seductive). Hal ini menurut Habermas mengakibatkan fragmentasi kesadaran sosial (fragmentation of social consciousness) (Lemert dan Elliott, 2014: 263).

Habermas menempatkan teori sosialnya dengan mengacu pada dunia kehidupan (lifeworld) (Lemert dan Elliott, 2014: 263). Dunia kehidupan merupakan ruang interaksi simbolik (symbolic interaction) dan dialog komunikatif (communicative dialogue), di mana setiap orang menghasilkan praktik tertentu serta menghadapi struktur sosial dalam kehidupan sehari-hari.

Sebagaimana dikatakan Habermas, masyarakat bertumbuh dan berkembang tidak hanya melalui teknologi, melainkan juga melalui interaksi simbolik atau tindakan komunikatif (communicative action) (Lemert dan Elliott, 2014: 264). Karena kehidupan sosial disusun melalui bahasa, komunikasi, dan pertukaran simbolik. Selain itu, kehidupan sosial mengandung dimensi kognitif dan moral.

Menurut Habermas, rasionalitas sistem dan rasionalitas dunia kehidupan menerapkan logika yang sepenuhnya berbeda. Terlepasnya sistem (system) dari dunia kehidupan (lifeworld) bukanlah tanda dominasi budaya. Sebagaimana diungkapkan Habermas, budaya modern tunduk pada kontrol administratif dan birokrasi. Dalam masyarakat modern, rasionalitas fungsional mengancam fondasi transmisi budaya, sosialisasi, dan pembentukan identitas diri manusia.
Habermas mengemukakan bahwa
negara bangsa mempunyai sarana yang memadai untuk menghadapi tantangan politik dan hukum yang ditimbulkan globalisasi (Lemert dan Elliott, 2014: 269). Oleh karena itu, dibutuhkan rasionalitas komunikatif (communicative rationality) yang berpusat pada proses demokratis pengambilan keputusan kolektif lintas batas teritorial. Karena tantangan moral dan politik tidak dapat diatasi dengan menggunakan teori globalisasi neo-liberal atau postmodern.

Gagasan Habermas menginspirasi ilmuwan sosial seperti Amy Gutmann, Seyla Benhabib, dan Iris Young. Mereka menggunakan gagasan Habermas mengenai rasionalitas komunikatif. Komunikasi yang bersifat transparan dan adil tersebut disebut para ahli ilmu sosial serta politik sebagai demokrasi deliberatif (deliberative democracy).

Konsepsi demokrasi deliberatif berakar kuat pada penilaian kolektif rakyat (collective judgment of the people). Menurut Amy Gutmann dan Dennis Thompson, dalam demokrasi deliberatif keputusan dibuat oleh warga negara dan perwakilan mereka (Lemert dan Elliott, 2014: 272). Selain itu, pemimpin harus memberikan alasan terkait keputusan yang diambil dan menanggapi pendapat warga negara.

\section{Zygmunt Bauman: Masyarakat Modern Diwarnai Deregulasi Ekonomi}

Bauman memeringatkan bahwa dunia global baru (new globalized world) ditandai ketidakpastian dan ambivalensi. Menurut Bauman, pasca-modernisasi menciptakan pola kekuasaan dan ketidaksetaraan serta peluang dan resiko bagi manusia (Lemert dan Elliott, 2014: 348. Terkait hal ini, Auschwitz merupakan hasil dari misi peradaban (civilizing) modernitas. Sehingga 
orang-orang Yahudi merupakan korban modernitas. Selanjutnya, Bauman melihat budaya postmodern menjadikan manusia sebagai orang luar (outsiders), orang asing (strangers), dan orang lain (others) (Lemert dan Elliott, 2014: 349).

Sebagaimana ditegaskan Bauman, postmodernitas ditandai ambivalensi dan ambiguitas (Lemert dan Elliott, 2014: 349). Terdapat celah antara praktik budaya modernis dan transformasi global postmodern yang menekankan deregulasi serta privatisasi. Pada zaman neo-liberal, ruang politik publik (public political space) menyusut drastis. Namun, pada saat bersamaan, pengalaman hidup (lifeexperience) dan kehidupan politik (lifepolitics) diawasi serta diatur. Menurut Bauman, pemerintah dewasa ini membiarkan masyarakat memainkan permainan mereka sendiri (Bauman, 2002: 68).

Pemerintah membiarkan masyarakat menyalahkan diri sendiri apabila hasil yang dicapai tidak sesuai harapan. Bahkan seringkali pemerintah menyampaikan tidak ada alternatif (there is no alternative), keamanan adalah ketergantungan (security is dependency), dan perlindungan negara melemahkan (state protection is disempowering) (Bauman, 2002: 68). Hal ini memerlihatkan pemerintah menghendaki supaya masyarakat bersikap fleksibel dan mencintai resiko (love the risk) ((Lemert dan Elliott, 2014: 350).

Modernitas merupakan proyek yang bersifat obsesif, ditandai keinginan untuk terus berubah (constant change) (Lemert dan Elliott, 2014: 351). Karena kemajuan dinilai tercapai apabila segala sesuatu yang dianggap lama diganti dengan yang baru. Sains dan teknologi merupakan pendorong utama manusia masuk ke dalam sistem klasifikasi rasional yang selalu baru. Sehingga modernitas mengedepankan rasionalitas konstan dan logika klasifikasi, menjauhkan serta meremehkan kekacauan dan ketidakpastian kehidupan sehari-hari. Karena modernitas mengejar keteraturan (order), stabilitas (stability), dan konsistensi (consistency).

Bauman melihat pentingnya ambivalensi bagi subjektivitas manusia, memperkaya tekstur afektif pengalaman interpersonal, dan melipatgandakan kompleksitas kehidupan sosial (Lemert dan Elliott, 2014: 351). Jika manusia menyadari ambivalensi, keragu-raguan, dan ketidakpastian sebagai unsur intrinsik kehidupan, maka ketergantungan sosial semakin meningkat. Namun, dalam modernitas ambivalensi dilarang, dinilai menyimpang, dan hina. Dengan kata lain, dorongan modernitas terhadap ketertiban merupakan dorongan rezim yang diatur oleh intolerasi (intolerance), ketidakfleksibelan (inflexibility), dan kekerasan simbolik (symbolic violence).

Menurut Bauman, lebih bermanfaat membicarakan postmodernitas daripada modernitas akhir (Bauman, 2001: 20). Karena postmodern pada dasarnya dibentuk budaya modern. Selain itu, tidak ada garis pemisah yang pasti antara postmodern dan modern. Postmodernitas merupakan tahap kesadaran diri dalam perkembangan modernitas (a self-conscious stage in the development of modernity) (Bauman, 2001: 20). Dimensi-dimensi postmodern memberi semangat dan membuka ruang pluralisasi imajinatif. Dalam modernitas, manusia bercita-cita untuk berkuasa, menghendaki kepastian, keteraturan, dan struktur.

Postmodern bagi Bauman tidak merepresentasikan transendensi, melainkan sebuah kemunduran. Hal ini terlihat dalam budaya populer dan teknologi komunikasi yang mengedepankan homogenitas, kontrol, ketertiban, dan kepastian (Lemert dan Elliott, 2014: 352). Menurut Bauman, segala sesuatu yang disadari dalam alam pikiran postmodern terkait dengan adanya masalah 
tanpa solusi, lintasan yang tidak dapat diluruskan, ambivalensi yang lebih daripada sekadar kesalahan linguistik, keraguan yang tidak dapat disalahkan, dan penderitaan moral yang tidak dapat disembuhkan (Bauman, 1993: 245).

Alam pikiran postmodern tidak menghendaki formula kehidupan tanpa ambiguitas, risiko, bahaya, dan kesalahan. Karena alam pikiran postmodern memilih berdamai dengan kekacauan (messiness) dan ketakutan (predicament) dalam hidup manusia (Bauman, 1993: 245). Perlu diketahui bahwa Bauman juga berbicara mengenai modernitas cair (liquid modernity) (Lemert dan Elliott, 2014: 353). Menurut Bauman, cairan (liquids) rentan terhadap perubahan, bersifat retak dan rapuh (Lemert dan Elliott, 2014: 354). Hal ini menggambarkan situasi dan kondisi sejarah modernitas.

Modernitas padat (heavy modernity), sebagaimana ditegaskan Bauman, mengambil peran dominan dalam perkembangan industrialisasi di Barat. Misalnya, mesin-mesin besar, pabrik-pabrik besar, dan tenaga kerja dalam jumlah besar. Oleh karena itu, kesuksesan ekonomi ditentukan dalam ukuran (size). Demikian juga kapitalisme padat (heavy capitalism), terobsesi dengan ukuran dan batasan yang ketat (tight) serta tidak bisa ditembus (impenetrable) (Bauman, 2000: 57).

Berdasarkan modernisme padat, masyarakat dimasukkan ke dalam ruang dan waktu tertentu. Di dalam ruang tersebut terjadi logika kontrol sosial (the logic of social control) dan logika kekuasaan simbolis (the logic of symbolic power). Terkait hal ini, fordisme (fordism) merupakan kesadaran diri masyarakat modern dalam fase padat (heavy), besar (bulky), tidak bergerak (immobile), mengakar (rooted), dan kokoh (solid) (Bauman, 2000: 57). Rutinitas waktu membuat ruang tersebut menjadi utuh, padat, dan tunduk pada logika homogen. Oleh karena itu, untuk menaklukkan ruang tersebut, waktu harus lentur (pliant) dan lunak (malleable) (Bauman, 2000: 57).

Modernitas padat dirusak oleh kontradiksi intrinsik, yaitu ambisi tatanan sosial, cita-cita etis, dan tujuan ekonomi serta politik yang korosif. Oleh karena itu, Bauman memperkenalkan gagasan modernitas ringan (light modernity) untuk menggantikan modernitas padat (heavy modernity). Hal ini terlihat dalam bangkitnya konglomerat multinasional, outsourcing manufaktur ke dunia berkembang (developing world), dan pergeseran investasi ke sektor komunikasi, keuangan, dan jasa.

Menurut Bauman, perkembangan tersebut menghasilkan likuidasi kehidupan (liquidization of life) dalam siklus bisnis, pola kerja, relasi keluarga, nasib komunal, dan cakrawala politik (Lemert dan Elliott, 2014: 355). Perlu diketahui bahwa modernitas cair (liquid modernity) tidak hanya membentuk institusi sosial, tetapi juga menembus kehidupan sehari-hari manusia. Terkait hal ini, kehidupan cair (liquid life) merupakan kehidupan yang genting, hidup dalam ketidakpastian (Lemert dan Elliott, 2014: 356).

\section{Membaca Fenomena Kabar Bohong Pilpres 2019 di Indonesia Berdasarkan Kaca Mata Herbert Marcuse, Jürgen Habermas, dan Zygmunt Bauman}

Iskandar dalam tulisannya berjudul "10 Hoaks Terkait Pemilu 2019" di liputan6.com 20 April 2019 melaporkan bahwa berita bohong atau hoaks merajalela sepanjang Pemilu 2019, baik semasa kampanye, saat pencoblosan, hasil hitung cepat hingga usai pencoblosan. Berita bohong tersebut membuat resah masyarakat. Kementerian Komunikasi dan Informatika 
(Kemkominfo) mengumpulkan sejumlah hoaks terkait Pemilu 2019.

Pertama, foto kompak penonton yang mengacungkan dua jari dalam acara millennial road safety festival. Kedua, quick count di Metro TV menyatakan Prabowo menang. Ketiga, mereka bukan lembaga survei tetapi tim sukses Jokowi. Keempat, di Bekasi ada 6.000 TPS dan Prabowo menang. Kelima, surat suara di Surabaya sudah tercoblos untuk paslon 01. Keenam, Sandiaga Uno diusir Prabowo karena tidak setuju deklarasi.

Ketujuh, quick count disebut sebagai bentuk kecurangan hasil pemilu. Kedelapan, hasil exit poll TPS di Malaysia, Filipina, Singapura, dan Thailand Prabowo-Sandi menang mutlak. Kesembilan, Amien Rais tidak percaya konstitusi, provokasi upaya mendelegitimasi KPU. Kesepuluh, Syekh Ali Jaber dukung Jokowi. Selanjutnya akan diuraikan gagasan Herbert Marcuse, Jürgen Habermas, dan Zygmunt Bauman dalam kaitannya dengan fenomena kabar bohong Pilpres 2019 di Indonesia.

Pertama, berdasarkan perspektif Marcuse, kabar bohong Pilpres 2019 di Indonesia merupakan salah satu akibat dari bertumbuh dan berkembangnya logika kapitalisme, mementingkan keuntungan serta mengabaikan kebenaran. Selain itu, manusia dilihat sekadar benda dan objek yang layak menerima kabar bohong. Sebagaimana dikatakan Marcuse, logika kapitalisme beroperasi pada tataran yang tidak disadari. Realitas menunjukkan bahwa seringkali manusia tidak menyadari bahwa berita yang diterimanya adalah kabar bohong.

Perlu diketahui bahwa kebohongan merupakan penindasan yang tidak kasat mata dan bisa membuat manusia mengalami represi. Oleh karena itu, dalam rangka mengantisipasi sikap mudah percaya terhadap suatu berita, manusia harus bersikap kritis, menyadari bahwa kapitalisme telah merambah subjektivitas kehidupan manusia. Pada tataran tertentu pemerintah harus ikut ambil bagian memperbaiki prinsip kinerja media, supaya mengedepankan dan menjunjung tinggi kebenaran, bukan kebohongan.

Kedua, berhadapan dengan kabar bohong Pilpres 2019 di Indonesia, perlu diupayakan dialog komunikatif. Jika masyarakat menerima suatu berita, maka yang bersangkutan harus mengonfirmasi kepada yang lain untuk memastikan kebenaran berita tersebut. Hal ini dalam gagasan Habermas disebut dialog komunikatif yang mengedepankan tanggung jawab etis.

Penting bagi pemerintah membudayakan diskursus di sekolah dan perguruan tinggi, supaya masyarakat mempunyai sikap kritis. Terutama agar masyarakat siap berhadapan dengan kabar bohong yang bersifat mematikan dan menggoda. Bahkan seringkali media digunakan sebagai senjata opini partai politik. Oleh karena itu, pengelola media harus bersikap transparan dan adil ketika menyampaikan berita kepada masyarakat.

Ketiga, jika kabar bohong Pilpres 2019 dilihat berdasarkan cara pandang Bauman, maka masyarakat pada dasarnya diperlakukan sebagai orang luar, orang asing, dan orang lain yang pantas menerima kabar bohong. Oleh karena itu, pemerintah tidak boleh membiarkan masyarakat menerima kabar bohong. Jika pemerintah bersikap apatis, maka sejatinya pemerintah menghendaki masyarakat mencintai resiko dalam bentuk mengonsumsi kabar bohong.

Menurut Bauman, dewasa ini masyarakat hidup dalam ketidakpastian. Ketidakpastian tersebut salah satunya nampak dengan maraknya kabar bohong yang dipublikasikan media. Dengan demikian, masyarakat harus menyadari adanya ketidakpastian tersebut dan bersikap kritis. 


\section{Penutup}

Realitas masyarakat satu dimensi seringkali menimbulkan kekerasan, penindasan, trauma, dan represi. Hal ini terlihat dalam kapitalisme yang memandang manusia sekadar sebagai objek dan benda. Selain itu, kapitalisme telah merambah ke dalam subjektivitas manusia. Bahkan dewasa ini kehidupan manusia tidak bisa lepas dari birokrasi dan teknologi. Hal ini mengharuskan manusia bersikap kritis yang dapat dilatih melalui dialog komunikatif. Supaya di tengah dunia yang terus mengalami kemajuan dalam semua bidang, manusia tidak menjadi orang luar, orang asing, dan orang lain.

\section{Daftar Pustaka}

Bauman, Zygmunt. 2000. Liquid Modernity. Cambridge: Polity Press.

1993. Postmodern Ethics. Oxford: Blackwell.

-----. 2002. Society under Siege. Cambridge: Polity Press.

-----. 2001. The Individual Society. Cambridge: Polity Press.

Habermas, Jürgen. 1995. "Reconciliation through the Public Use of Reason: Remarks on John Rawls Political Liberalism." Jurnal of Philosophy. Vol. 92, No. 3.

Lemert, Charles C. dan Anthony Elliott. 2014. Introduction to Contemporary Social Theory. New York: Routledge.

Marcuse, Herbert. 1964. One-Dimensional Man. Boston: Beacon Press.

\section{Internet:}

Iskandar. "10 Hoaks Terkait Pemilu 2019." https://www.liputan6.com/tekno/read/ 3946007/10-hoaks-terkait-pemilu2019. Diakses pada 13 November 2020 pukul 13.00 WIB. 